\title{
A Comparison of Grid-connected Battery Energy Storage System Designs
}

\author{
Efstratios Chatzinikolaou, Student Member, IEEE and Daniel J. Rogers, Member, IEEE
}

\begin{abstract}
This paper presents a method for evaluating gridconnected Battery Energy Storage System (BESS) designs. The steady-state power losses of the grid interface converter, the battery pack and the balancing circuit are calculated. The reliability of each complete system is calculated using a Markovbased modelling approach that takes into account the built-in redundancy of the system as well as performance degradation caused by faults. Finally, a simple economic analysis based on capital cost and efficiency is used to provide a basis for direct comparison between competing system designs. Three design options for a $1 \mathrm{MW}, 1 \mathrm{MWh}$ BESS connected at $11 \mathrm{kV}$ are compared: a conventional BESS using parallel low-voltage power blocks, a BESS using a high-voltage intelligent battery pack and a BESS using a cascaded H-bridge converter. The results of the analysis indicate that additional power electronics included in the battery pack as part of the intelligent battery pack and $\mathrm{H}$-bridge designs can enhance the reliability of the BESS by an order of magnitude under typical conditions, without increasing the overall cost of the system.
\end{abstract}

Index Terms - Battery Energy Storage, Markov models, multilevel converter, reliability

\begin{tabular}{|c|c|}
\hline & NOMENCLATURE \\
\hline$P_{\mathrm{CN}}, P_{\mathrm{SW}}$ & $\begin{array}{l}\text { Conduction and switching losses } \\
\text { semiconductors }(\mathrm{W}) \text {. }\end{array}$ \\
\hline$P_{\mathrm{BP}}$ & Battery pack losses of the BESS (W). \\
\hline$P_{\text {bal }}$ & Balancing losses of the BESS (W). \\
\hline$P_{\mathrm{C}}$ & $\begin{array}{l}\text { Lithium ion cell power losses due to internal } \\
\text { resistance (W). }\end{array}$ \\
\hline $\begin{array}{l}I_{\mathrm{RMS}}, V_{\mathrm{RMS}} \\
\cos \theta\end{array}$ & $\begin{array}{l}\text { RMS value of BESS output current, voltage } \\
(A, V) \text { and power factor. }\end{array}$ \\
\hline$M$ & Modulation ratio of 2-level converter. \\
\hline$I_{\mathrm{C}}$ & Lithium ion cell DC current (A). \\
\hline$I_{\mathrm{rms}(\mathrm{i})}$ & $\begin{array}{l}\text { RMS current in the CHB-BESS of the } i \text { th } \\
\text { Lithium ion cell (A). }\end{array}$ \\
\hline$V_{\mathrm{D}}, V_{\mathrm{Q}}$ & $\begin{array}{l}\text { On-state voltage drop of an IGBT or diode } \\
\text { (V). }\end{array}$ \\
\hline$V_{\mathrm{M}}$ & Battery module nominal voltage $(\mathrm{V})$ \\
\hline$V_{\mathrm{pk}}$ & Peak AC output voltage of the BESS (V). \\
\hline$V_{\max }$ & Battery module maximum voltage $(\mathrm{V})$. \\
\hline$V_{\mathrm{C}}$ & Lithium ion cell nominal voltage (V). \\
\hline$R_{\mathrm{Q}}, R_{\mathrm{D}}$ & On-state resistance of an IGBT or Diode $(\Omega)$. \\
\hline$R_{\mathrm{F}}$ & On-state resistance of a MOSFET $(\Omega)$. \\
\hline
\end{tabular}

Manuscript received July 21, 2016; revised September 12, 2016; accepted November 06, 2016. This work was supported in part by the UK Engineering and Physical Sciences Research Council under grant EP/K002252/1.

E. Chatzinikolaou and D. J. Rogers are with the Energy and Power Group, Department of Engineering Science, University of Oxford, Oxford, U.K. (e-mails: efstratios.chatzinikolaou@worc.ox.ac.uk, dan.rogers@eng.ox.ac.uk).

$R_{\mathrm{C}}$
$k_{\text {on } / \text { off }}$
$f_{\mathrm{SW}}$
$N_{\mathrm{C}}, N_{\mathrm{M}}$
$n_{\mathrm{C}}$
$n_{\mathrm{P}}, n_{\mathrm{S}}$
$N_{\mathrm{P}}, N_{\mathrm{S}}$
$N_{\mathrm{PB}}$
$N_{\mathrm{SS}}$
$N_{\mathrm{HB}}$
$N_{\mathrm{a}}$

$r_{\mathrm{v}}$

$r_{\mathrm{e}}$

$T$

$Q_{\mathrm{M}}$

$Q_{\min }$

$P_{i}(t)$

MTTF

$\lambda_{\mathrm{C}}$

$\lambda_{\mathrm{V}}$

$\lambda_{\mathrm{A}}$

$\lambda_{\mathrm{X}}$

$\lambda_{\mathrm{D}}$

$\lambda_{\mathrm{Q}}$

$\lambda_{\mathrm{F}}$

$\lambda_{\mathrm{R}}$

$\lambda_{\mathrm{M}}$

$\lambda_{\mathrm{P}}$

$\lambda_{\mathrm{W}}$

$\lambda_{\mathrm{A}}$

$\lambda_{\mathrm{H}}$

$\lambda_{\Theta}$

$\mathrm{D}, \mathrm{Q}$ $\mathrm{PB}, \mathrm{IBP}$, $\mathrm{CHB}$
Internal resistance of a lithium ion cell $(\Omega)$. Switching loss constant calculated using the datasheet information (W/(A Hz)).

Switching frequency of 2-level converter (Hz).

Total number of cells and cell modules in a BESS.

Number of cells within a module.

Number of parallel strings and series modules in a PB-BESS.

Number of parallel and series modules in a IBP-BESS.

Number of power blocks in a PB-BESS.

Number of series connected IGBTS in an arm of the centralized converter of the IBP-BESS.

Number of H-Bridge converter modules in each phase of the CHB-BESS.

Number of additional cells for over-provision in the PB-BESS.

Voltage redundancy ratio.

Energy redundancy ratio.

Period of grid voltage/current waveform (s).

Nominal module capacity (Ah).

$=0.95 Q_{\mathrm{M}}$. Minimum module capacity $(\mathrm{Ah})$.

Probability of the system being in state $i$ at time $t$.

Mean time to failure $\left(10^{6} \mathrm{~h}\right)$.

FAILURE RATES (failures $/ 10^{6} \mathrm{~h}$ )

Of lithium ion cell.

Of power converter.

Of capacitor.

Of transformer.

Of diode.

Of IGBT.

Of MOSFET.

$=n_{\mathrm{S}} n_{\mathrm{C}} \lambda_{\mathrm{C}}$. Of a string of cells in a PB-BESS.

$=n_{\mathrm{C}} \lambda_{\mathrm{C}}$. Of cell module.

$=\left(\lambda_{\mathrm{M}}+\lambda_{\mathrm{F}}\right) N_{\mathrm{P}}$. Of parallel modules in a IBP-

BESS.

$=\lambda_{\mathrm{Q}}+\lambda_{\mathrm{D}}$. Of a switching device.

Of converter arm in IBP-BESS.

$=4 \lambda_{\mathrm{F}}$. Of an H-Bridge.

Of one phase in a CHB-BESS.

$$
\text { SUPERSCRIPTS }
$$

Diode, IGBT.

BESS topology (Power Block, Intelligent Battery Pack and Cascaded H-Bridge). 


\section{INTRODUCTION}

$\mathrm{T}$ HE nominal voltage of electrochemical cells is much lower than the connection voltage of grid-scale energy storage applications: Lithium-ion chemistries typically produce 3-3.7 V per cell whereas Battery Energy Storage Systems (BESSs) larger than $1 \mathrm{MW}$ and $1 \mathrm{MWh}$ are typically connected to the lower distribution network at medium voltage (MV) e.g. $11 \mathrm{kV}$ in the UK [1]. It is standard practice to connect 200-300 cells in series to achieve a DC bus voltage of approximately $600 \mathrm{~V}$, which is converted to $\mathrm{AC}$ and stepped up to the grid connection voltage using a three phase bridge and a line-frequency transformer [2,3]. A series connection of cells requires specialised circuits installed as part of the Battery Management System (BMS) to compensate for inherent variations in cell characteristics. These variations are initially caused by the manufacturing process and tend to increase during operation, e.g. uneven pack temperature causing different rates of cell aging and capacity fade [4]. Without additional management circuits, the cell with the lowest capacity will limit the operation of the string by reaching the high or low cut-off voltage before the rest of the cells, causing charge or discharge to terminate while there is still capacity available in the string. In order to overcome these limitations, passive or active balancing approaches equalise the state of charge $(\mathrm{SoC})$ between individual cells. In passive balancing, energy is dissipated through shunt resistors whereas in active approaches, energy is redistributed among cells by using additional storage devices (capacitors, inductors) [5]. Although passive balancing is an energy dissipative method, it is often preferred due to its low cost and relatively simple implementation [6].

A further issue that arises with the series connection of a high number of cells is the decreased reliability of the battery pack, since a single cell failure can cause failure of the whole pack if appropriate protective measures have not been incorporated. As the power and energy rating of the system increases, a parallel configuration of complete battery energy storage systems, referred to in this paper as power blocks, is often used to avoid the construction of a very large monolithic battery pack. Here, the total capacity is divided between several identical smaller systems which operate together (Fig. 1a) [7]. An advantage of this arrangement is that failure of one cell will cause the loss of only one series string in one power block [8], as opposed to a much larger series string as would be found in a monolithic system. A drawback is that the economies of scale inherent in a monolithic system are lost. For example, the high current on the battery-side transformer windings (due to the low DC bus voltage) causes a relatively bulky transformer design [9].

An alternative design is the intelligent battery pack [10] that incorporates a combination of two power MOSFETs, one in series and one in parallel with the cell, in order to bypass the cell in case of failure. For a large scale system with a high number of cells, using a bypass circuit for each cell may become impractical so the proposed bypass method is implemented at a module level [11]. However, the important result is that this creates an ability to manage a cell failure online by isolating a single module rather than a whole pack. The switching arrangement also enables 'built-in' active module balancing by controlling the effective duty cycle of module with respective to the average of the pack.

Considering the above, when designing a BESS for connection at MV levels it is not clear whether the best solution is a parallel combination of power blocks using simple battery packs (with passive balancing and a relatively low number of cells in series) coupled to the grid using stepup transformers (Fig. 1a), or investing in a larger intelligent battery pack that allows a large number of cells to be connected in series which is then interfaced to an MV power converter connected directly to the grid (Fig. 1b).

A fundamentally different approach to the separate battery pack and converter approach is the modular Cascaded $\mathrm{H}$ bridge (CHB) multilevel converter, where the power converter is essentially 'distributed' with the cells, as opposed to being a centralised unit. The CHB circuit (Fig. 1c) is an attractive BESS solution due to the inherent advantages of the multilevel topology such as the use of low voltage switches, low switching frequency operation and very high output voltage quality $[8,12]$ leading to minimal filtering requirements. In BESS applications a major advantage of the CHB is that it provides complete control over each module, allowing the implementation of balancing schemes without a need for additional balancing circuits [13, 14]. It also allows modules with failed cells to be bypassed without affecting operation of the overall system. The system is inherently scalable to higher voltages and can include redundant cells to provide high reliability. Although the CHB provides a very high degree of controllability and may improve battery utilisation and, for example, facilitate integration of second life batteries [15], the high number of switches required and the subsequent cost, power losses and reliability concerns when compared to conventional converter topologies raises issues regarding the apparent feasibility of such a system.

This paper provides a comparison of three BESS design options: A conventional design using parallel power blocks (PB-BESS), a design using intelligent battery packs (IBPBESS), and a cascaded H-bridge design (CHB-BESS). For each option the steady-state operating power losses are calculated, a model of system reliability is developed and the capital cost of the complete system is estimated. All designs are specified to provide $1 \mathrm{MWh}$ storage capacity, a rated power of $1 \mathrm{MW}$ and are to be connected to the distribution network at $11 \mathrm{kV}$.

\section{POWER LOSS ANALYSIS}

Loss calculations in all three cases take into account converter losses and cell losses due to internal cell resistance.

\section{A. Converter losses}

The power losses of a switching device are calculated as the sum of conduction $\left(P_{\mathrm{CN}}\right)$ and switching losses $\left(P_{\mathrm{SW}}\right)$ [16]. For the IGBT and diode, conduction losses are modelled as a forward voltage plus slope resistance [17], for the MOSFET, only a resistance is used [18]. 


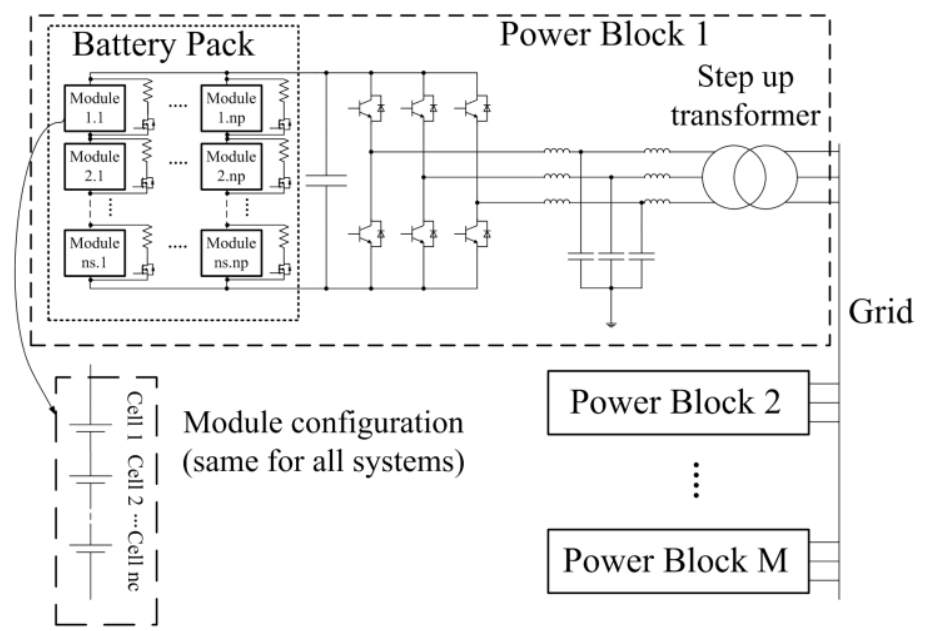

(a)

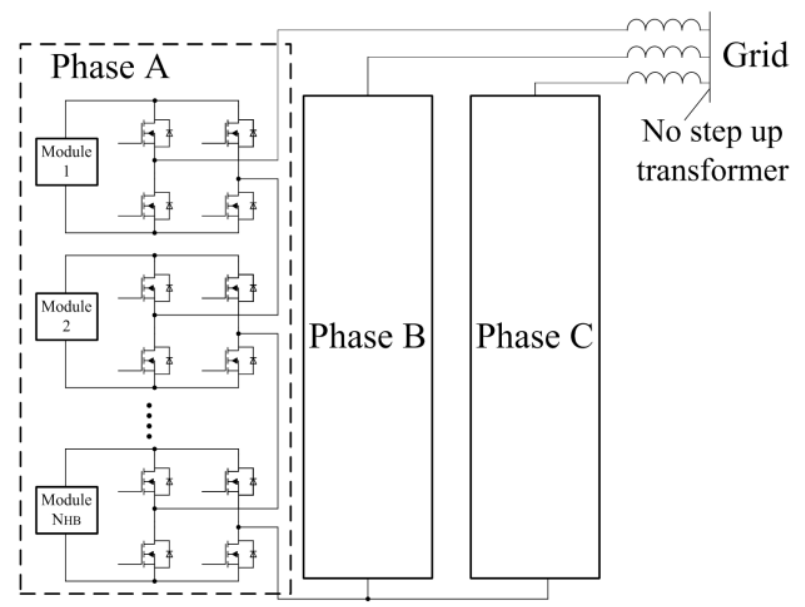

(c)

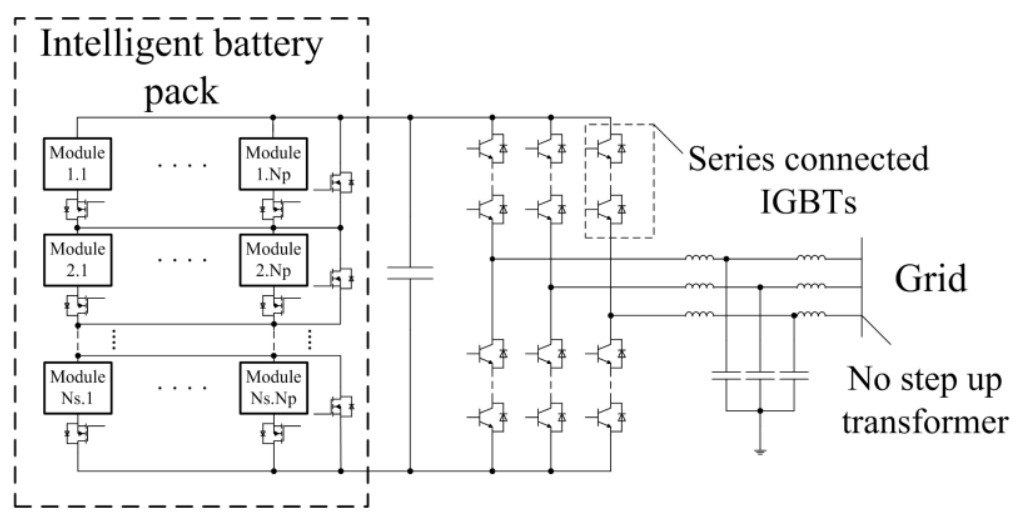

(b)

Fig. 1. (a) BESS using a parallel power block configuration. (b)BESS using an intelligent battery pack with a single-stage two-level converter interface. (c) BESS using a cascaded H-bridge multilevel converter.

The switching losses are calculated as the sum of turn-on and turn-off losses for IGBTs and MOSFETs. For the diodes, only losses at diode turn-off are considered significant. A simple model of switching losses is used where a linear relationship between losses and device current at the instant of switching is assumed, with the constants of proportionality estimated using the manufacturer's datasheet [17].

The total power converter losses are then given in (1)-(2) for the different BESS configurations [17]. For the centralised power converters of the PB-BESS and IBP-BESS:

$$
\begin{aligned}
& P_{\mathrm{CN}}^{\mathrm{PB} / \mathrm{IBP}} \\
& \quad=6\left(\sqrt{2} I_{\mathrm{RMS}}\left(\frac{1}{2 \pi}+\frac{M \cos \theta}{8}\right) V_{\mathrm{Q}}\right. \\
& \quad+2 I_{\mathrm{RMS}}^{2}\left(\frac{1}{8}+\frac{M \cos \theta}{3 \pi}\right) R_{\mathrm{Q}} \\
& \quad+\sqrt{2} I_{\mathrm{RMS}}\left(\frac{1}{2 \pi}-\frac{M \cos \theta}{8}\right) V_{\mathrm{D}} \\
& \left.\quad+2 I_{\mathrm{RMS}}^{2}\left(\frac{1}{8}-\frac{M \cos \theta}{3 \pi}\right) R_{\mathrm{D}}\right) N \\
& P_{\mathrm{SW}}^{\mathrm{PB} / \mathrm{IBP}}=\frac{6 \sqrt{2}}{\pi}\left(k_{\mathrm{on}}^{\mathrm{Q}}+k_{\mathrm{off}}^{\mathrm{Q}}+k_{\mathrm{on}}^{\mathrm{D}}\right) f_{\mathrm{SW}} I_{\mathrm{RMS}} N
\end{aligned}
$$

where $N$ is equal to $N_{\mathrm{PB}}(\mathrm{PB})$ or $N_{\mathrm{SS}}$ (IBP)

For the CHB-BESS the calculation of converter power loss is substantially different because of the distributed nature of the converter and the use of many low voltage MOSFETs in place of a small number of higher voltage IGBTs. During operation of the CHB-BESS, due to the cascaded arrangement of the H-bridges, two MOSFETs are always conducting the load current even when the module is bypassed (Fig. 2). The total conduction loss for the three-phase CHB-BESS is given by

$$
P_{\mathrm{CN}}^{\mathrm{CHB}}=6 N_{\mathrm{HB}} I_{\mathrm{RMS}}^{2} R_{\mathrm{F}}
$$

The switching strategy of the CHB-BESS is based on a nearest voltage algorithm described in [19], resulting in a very low effective switching frequency of $100 \mathrm{~Hz}$. In this case, the switching losses are negligible compared to the conduction losses of the MOSFET and so are neglected.

In the $\mathrm{PB}$, transformer losses are assumed to be $1 \%$ which is commensurate with a 1 MVA class transformer operated at a high load factor [20]. Control system, cooling, LCL filter and DC link capacitor losses in the PB and IBP as well as the losses in the CHB output inductors are assumed to be small compared to other losses and so are neglected [21]. 


\section{B. Battery pack losses}

Cell losses are assumed to be the result of an internal cell resistance only. In this study it is assumed that the internal resistances of all cells are similar, cell capacities vary across a small range (5\% in the following case study) and the system is operated at a low $\mathrm{C}$ rate. As a result the difference in cell currents across parallel connected cells will be small and cell power losses will be similar throughout the system (this assumption would not be valid at high $\mathrm{C}$ rates associated with EV applications and a more detailed model would be required [22-24]). All cells are therefore modelled as having an identical resistance $R_{C}$ that represents an average cell power loss. In order to calculate total cell power losses for the conventional battery pack of a power block, converter power losses are neglected so that $\mathrm{DC}$ and $\mathrm{AC}$ power are related by

$$
n_{\mathrm{P}} n_{\mathrm{S}} V_{\mathrm{M}} I_{\mathrm{C}}=\sqrt{3} V_{\mathrm{RMS}} I_{\mathrm{RMS}} \cos \theta
$$

and

$$
r_{\mathrm{v}} n_{\mathrm{S}} V_{\mathrm{M}}=\sqrt{2} V_{\mathrm{RMS}}
$$

The voltage redundancy ratio $r_{v}=\frac{V_{\mathrm{pk}}}{n_{\mathrm{S}} V_{\mathrm{M}}}\left(=\frac{V_{\mathrm{pk}}}{N_{\mathrm{S}} V_{\mathrm{M}}}=\right.$ $\left.\frac{V_{\mathrm{pk}}}{N_{\mathrm{HB}} V_{\mathrm{M}}}\right) \leq 1$ is defined as the number of cells required to provide the peak $\mathrm{AC}$ output voltage divided by the total number of cells in a series string. Later in the paper, the term $r_{e}=\frac{E_{\mathrm{n}}}{N_{\mathrm{C}} V_{\mathrm{C}} Q_{\mathrm{C}}} \leq 1$ is defined as the energy redundancy ratio, equal to the number of cells required to provide the rated energy $E_{\mathrm{n}}$, divided by the total number of cells $N_{\mathrm{C}}$. In all three systems $r_{\mathrm{e}} \geq r_{\mathrm{v}}$ in order to ensure that the failure criterion for each system is loss of rated power and energy delivery capability, not loss of voltage availability. It should be noted that, in practice, third harmonic injection would likely be used to increase the effective output voltage of the converter (i.e. lower the effective $V_{\mathrm{pk}}$ ), however it is not included here in order to simplify the analysis.

By solving (5) for $V_{M}$ and substituting into (4), the total cell losses for the PB-BESS are

$$
\begin{aligned}
P_{\mathrm{BP}}^{\mathrm{PB}} & =n_{\mathrm{C}} n_{\mathrm{S}} n_{\mathrm{P}} N_{\mathrm{PB}} P_{\mathrm{C}} \\
& =\frac{3}{2 n_{\mathrm{P}}} n_{\mathrm{C}} n_{\mathrm{S}} N_{\mathrm{PB}} r_{\mathrm{v}}^{2} \cos ^{2} \theta I_{\mathrm{RMS}}^{2} R_{\mathrm{C}}
\end{aligned}
$$

Similarly, for the IBP-BESS the total cell losses are:

$$
P_{\mathrm{BP}}^{\mathrm{IBP}}=\frac{3}{2 N_{\mathrm{P}}} n_{\mathrm{C}} N_{\mathrm{S}} r_{\mathrm{v}}^{2} \cos ^{2} \theta I_{\mathrm{RMS}}^{2} R_{\mathrm{C}}
$$

In case of the CHB-BESS, the current is different for each module depending on the operation of the nearest voltage matching algorithm [19]. From Fig. 2 it can be observed that module current varies according to the instance each module is inserted in the load current path and the respective duty cycle. The instance $t_{i}$ of each half period when a module is switched is found by solving

$$
\sqrt{2} V_{\mathrm{RMS}} \cos \left(\frac{2 \pi t_{i}}{T}\right)=V_{\mathrm{M}}(i-0.5) \quad \begin{aligned}
& \\
& i=1 . . r_{\mathrm{v}} N_{\mathrm{HB}}
\end{aligned}
$$

The RMS value of the cell current may then be calculated using

$$
I_{\mathrm{rms}(i)}=\sqrt{4 I_{\mathrm{rms}}^{2}\left(\frac{t_{i}}{\mathrm{~T}}+\frac{\sin \left(\frac{4 \pi t_{i}}{T}\right) \cos (2 \theta)}{4 \pi}\right)}
$$

Finally the cell power losses for the CHB-BESS can be found using the average cell rms current:

$$
\begin{aligned}
P_{\mathrm{BP}}^{\mathrm{CHB}} & =3 N_{\mathrm{HB}} n_{\mathrm{C}} P_{\mathrm{C}}=3 n_{\mathrm{C}} R_{\mathrm{C}} \sum_{1}^{r_{v} N_{\mathrm{HB}}} I_{\mathrm{rms}(i)}^{2} \\
\cong & \frac{6}{\pi} n_{\mathrm{C}} N_{\mathrm{S}} r_{\mathrm{v}}\left(\frac{\cos (2 \theta)}{3}+1\right) I_{\mathrm{RMS}}^{2} R_{\mathrm{C}}
\end{aligned}
$$

\section{Over-provision of cells and cell balancing}

Some variation in the capacities of nominally identical new cells is always observed due to manufacturing tolerences and, as cells are cycled, the variation tends to increase over time [25]. As the accessible capacity of a series string of cells is limited to that of the lowest capacity cell additional cells must be included in the PB-BESS to guarantee the rated energy capacity can be provided as the system ages. The number of additional cells (over-provision) depends on the worst case variation between the nominal and minimum capacity of the cells:

$$
N_{\mathrm{a}}=\frac{N_{\mathrm{C}}\left(Q_{\mathrm{M}}-Q_{\min }\right)}{Q_{\min }}
$$

This effect also occurs within modules in the IBP and CHB-BESS designs but because full active balancing can be performed between modules, the impact on the capacity of the series connection of modules is negligible, i.e. effectively all capacity is accessible from all cells despite variation in cell capacity.

A passive balancing circuit is also considered for the PBBESS. However, passive balancing is only performed periodically (once every few cycles) to equalize the module voltages at the end of a charging cycle: Once a module reaches the cut off voltage it is clamped at this voltage by external circuitry and energy dissipated resistively while the rest of the modules continue to be charged, normally at a lower $\mathrm{C}$ rate [5]. As a result, passive balancing losses in the PB-BESS will depend on the operating regime and the requirements of the particular cell technology, making them difficult to model in a general sense. However, if balancing only occurs infrequently, overall losses will be relatively small and so they are neglected in this study.

In the case of the IBP-BESS and CHB-BESS, balancing at module level is achieved by controlling each module's effective duty cycle by appropriately switching the MOSFETs and exploiting module redundancy. For the IBP, the losses in the pack MOSFETs can effectively be assigned to the balancing operation and are therefore referred to as balancing losses (i.e. the pack MOSFETs are 'used' to perform balancing only and do not perform a direct power conversion function as in the CHB). When a module is in-circuit the 
MOSFET in series with the module is turned on, whereas when a module is bypassed the MOSFET in parallel is turned on, i.e. there is always one MOSFET conducting in each module. The balancing losses for the IBP-BESS are therefore

$$
P_{\mathrm{bal}}^{\mathrm{IBP}}=\frac{3}{2 N_{\mathrm{P}}} N_{\mathrm{S}} r_{\mathrm{v}}^{2} \cos ^{2} \theta I_{\mathrm{RMS}}^{2} R_{\mathrm{F}}
$$

For the CHB-BESS, balancing losses are zero because balancing is an intrinsic part of system operation (i.e. balancing is 'free' as conduction losses in the MOSFETs of each H-bridge have already been accounted for in the converter loss calculation).

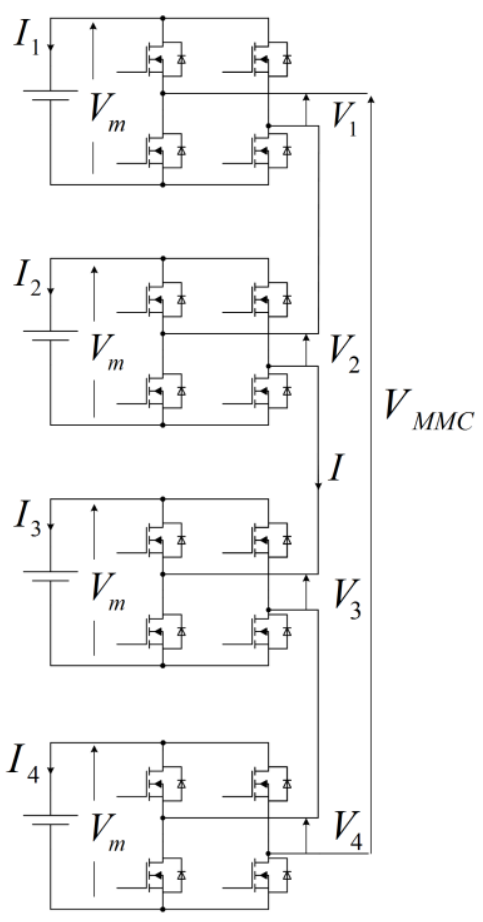

(a)
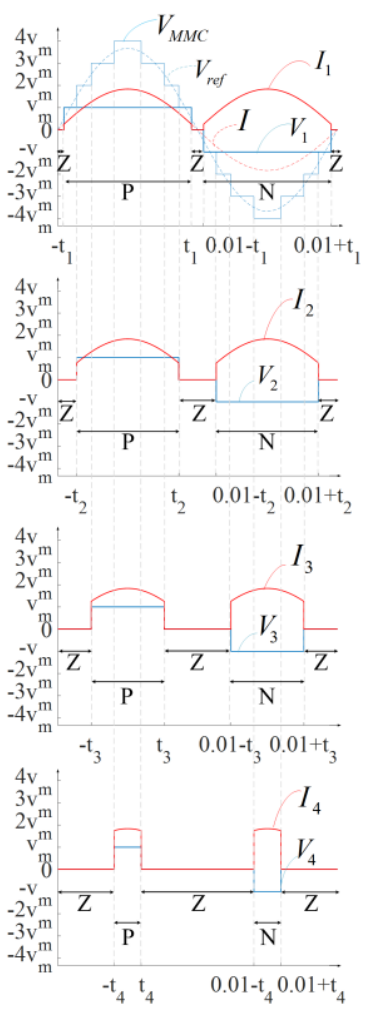

(b)

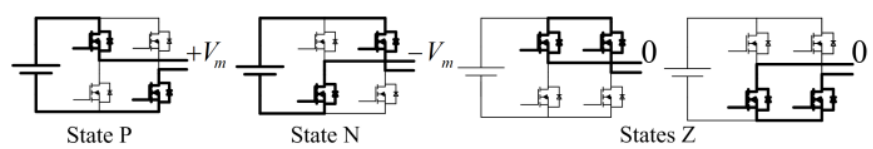

(c)

Fig. 2. (a) 9-level cascaded H-bridge converter. (b) Switching operation of a 9-level cascaded H-bridge converter. (c) Operational states of each H-bridge.

\section{RELIABILITY ANALYSIS}

Studies focusing on BESS reliability are limited in the current literature although several examples of similar studies can be found for various converter topologies and applications such as photovoltaic systems [26, 27] and wind turbines [2831]. In most cases, a relatively simple approach is followed where the reliability of the system under study is calculated as the sum of the respective failure rates of the system components, referred to as the 'parts count method' [32]. An example of this approach is the study of power loss, reliability and cost of a $1 \mathrm{MW} / 500 \mathrm{kWh}$ BESS [33] in which the failure rate of each electrochemical cell is calculated based on the stress imposed on the internal cell resistance using MILHDBK-217F [34] and failure rate of the system is calculated as the sum of the local failure rates without considering inbuilt system redundancy. In [27] a methodology is presented for calculating system reliability using Markov-based models. The advantage of this methodology is that it takes into account the steady state behaviour of the system to specify each component's failure rate. This paper applies such Markovbased models in the analysis of BESSs, taking into account built-in redundancy and varying failure rates as components fail (so-called 'state dependent failure rates'). This process is described in Fig. 3. All three systems are assumed to have failed when the rated power can no longer be provided, i.e. when a predefined number of cells have failed or become unusable because their associated power converter has failed. All cells and converter components are active throughout the operation of the system so during steady state all share the same failure rates (i.e. replacement cells are not kept idle and then 'switched in' after failure). After a component failure, the steady state loading of the remaining components is altered (increased) in order to maintain a constant power output and this change is reflected in an increased failure rate. For example, after losing one module in the any of the three systems, the remaining modules must be operated at a higher $\mathrm{C}$ rate to maintain the same output power, resulting in greater internal heating of the cells and an increased cell failure rate.

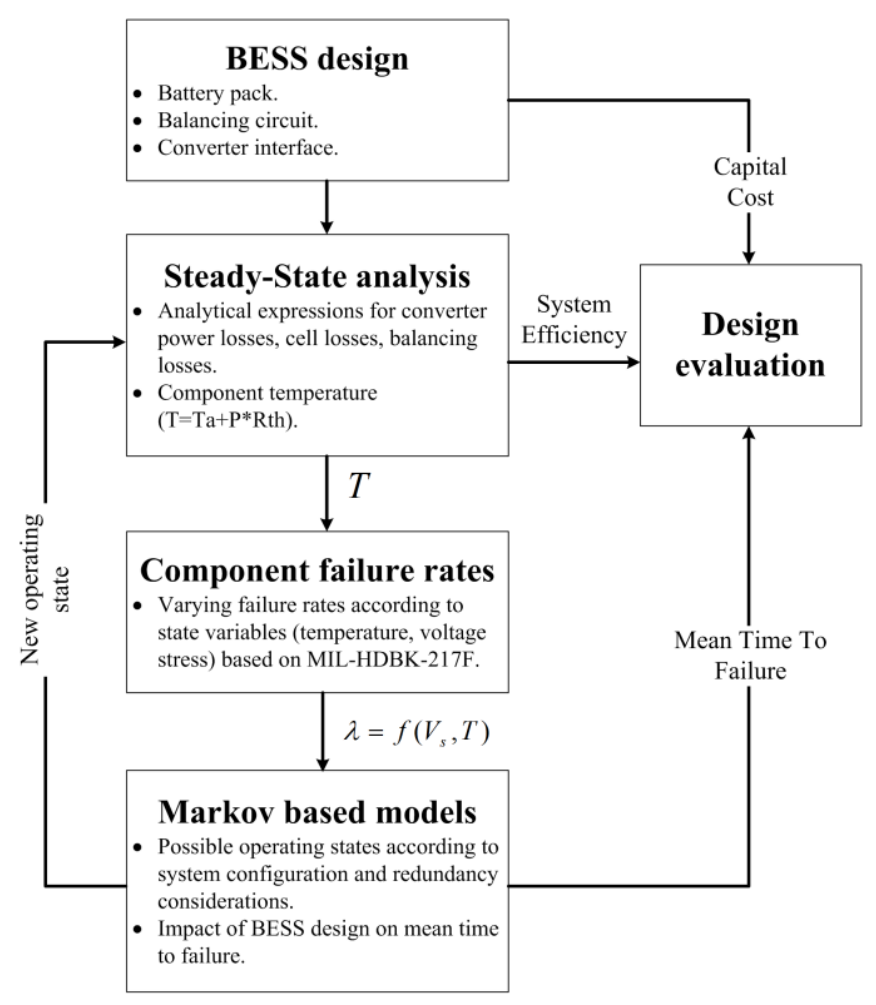

Fig. 3. BESS design evaluation methodology. 


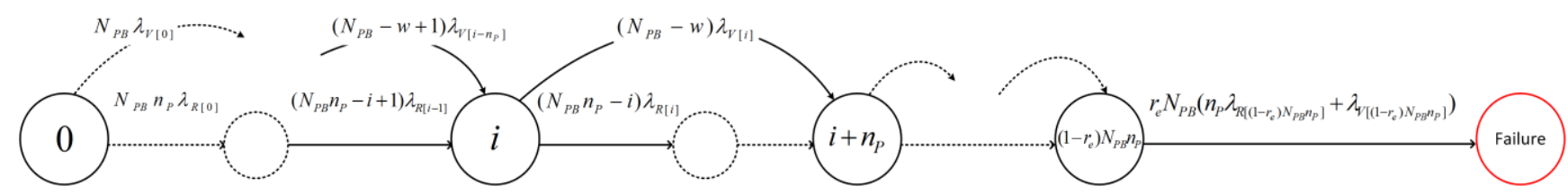

Fig. 4. Markov state transition diagram of the PB-BESS.

\section{A. Power block system reliability}

In conventional battery packs, failure of a single module is addressed by isolating the whole series string of modules containing the failed module [8]. The PB-BESS will continue to operate normally as long as $N_{\mathrm{PB}} n_{\mathrm{P}} r_{\mathrm{e}}$ parallel strings are available. The Markov state transition diagram for the PBBESS is presented in Fig. 4. $P_{i}$ represents the probability of the system being in a steady state where $i$ parallel strings have failed. The failure rate (expected failures per million hours) describing a transition from state $i$ to $(i+1)$ is $\left(N_{\mathrm{PB}} n_{\mathrm{P}}-\right.$ i) $\lambda_{\mathrm{R}[i]}$. A failure of a power converter will cause the system to lose $n_{\mathrm{P}}$ strings and move to state $P_{i+n_{\mathrm{P}}}$ with a transition rate $\left(N_{\mathrm{PB}}-w\right) \lambda_{\mathrm{V}[i]}$ where $w$ is the number of failed PBs at the state $P_{i}$. Note that that all the cells in the PB-BESS are assumed to be operated under equal $\mathrm{C}$ rates ${ }^{1}$ in order to maintain access to the capacity of each cell.

According to Fig. 4 the system's operating behavior is described by (13)-(16) (at time $t=0$ the system is assumed to be in state 0 , i.e. $P_{0}(0)=1$ and $P_{i}(0)=0$ for $\left.i>0\right)$.

$$
\begin{aligned}
& \frac{\mathrm{d} P_{0}}{\mathrm{~d} t}=-\left(N_{\mathrm{PB}} \lambda_{\mathrm{V}[0]}+N_{\mathrm{PB}} n_{\mathrm{P}} \lambda_{\mathrm{R}[0]}\right) P_{0} \\
& \frac{\mathrm{d} P_{i}}{\mathrm{~d} t}=\left(N_{\mathrm{PB}}-w+1\right) \lambda_{\mathrm{V}\left[i-n_{\mathrm{P}}\right]} P_{i-n_{\mathrm{P}}} \\
& +\left(N_{\mathrm{PB}} n_{\mathrm{P}}-i+1\right) \lambda_{\mathrm{R}[i-1]} P_{i-1}-\left(\left(N_{\mathrm{PB}} n_{\mathrm{P}}\right.\right. \\
& \left.-i) \lambda_{\mathrm{R}[i]}+\left(N_{\mathrm{PB}}-w\right) \lambda_{\mathrm{V}[i]}\right) P_{i} \\
& i=1 . . N_{\mathrm{PB}} n_{\mathrm{P}}\left(1-r_{\mathrm{e}}\right)
\end{aligned}
$$

Since the DC link capacitor, transformer and converter semiconductors are a series system in terms of reliability [35], the failure rate of the power converter is given by

$$
\lambda_{\mathrm{V}}=\lambda_{\mathrm{A}}+\lambda_{\mathrm{X}}+6\left(\lambda_{\mathrm{Q}}+\lambda_{\mathrm{D}}\right)
$$

According to [27] the mean time to failure (MTTF) of the system can be calculated using the Laplace transformation of $P_{i}, P_{i}^{*}$ :

$$
\mathrm{MTTF}_{\mathrm{PB}}=\sum_{i=0}^{N_{\mathrm{PB}} n_{\mathrm{P}}\left(1-r_{\mathrm{e}}\right)} P_{i}^{*}(0)
$$

\footnotetext{
${ }^{1}$ As a result, the converters that correspond to PBs with all their cells operational are stressed more than those with failed strings. However, in the analysis presented here it is assumed that the load on all PB converters increases equally after the failure of a string of cells. This is done to significantly reduce the number of states and transitions required in the Markov model.
}

\section{B. Intelligent battery pack system reliability}

For the reliability assessment of the IBP-BESS it is assumed that the pack can operate as long as $r_{\mathrm{e}} N_{\mathrm{S}}$ parallel connected module blocks (with a parallel bypass MOSFET) are operational. The Markov state transition diagram for the IBP is presented in Fig.5. $P_{i j}$ represents the probability of the pack being in a state where $i$ parallel module blocks have failed and are bypassed by their parallel MOSFETs, while $j$ parallel MOSFETs from the remaining module blocks have failed closed circuit ${ }^{2}$. A transition from a state $i j$ to $(i+1) j$ is realized with a failure rate $\left(N_{\mathrm{S}}-i-j\right) \lambda_{\mathrm{P}[i j]}$ and to $i(j+1)$ with a failure rate $\left(N_{\mathrm{S}}-j-i\right) \lambda_{\mathrm{F}[i j]}$.

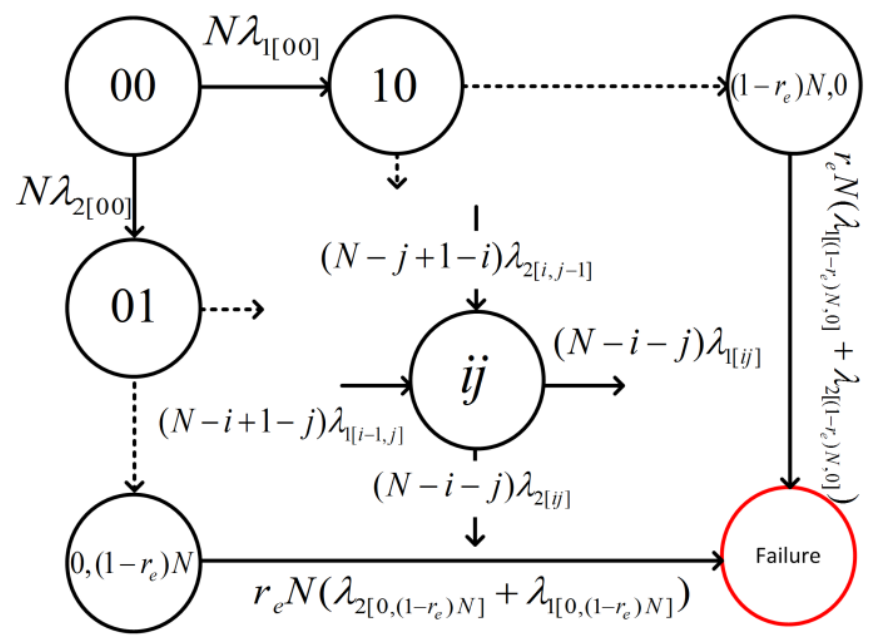

Fig. 5. Markov state transition diagram for the IBP-BESS and CHB-BESS. For the IBP-BESS $N=N_{S}, \lambda_{1}=\lambda_{P}, \lambda_{2}=\lambda_{F}$. For the CHB-BESS $N=$ $N_{H B}, \lambda_{1}=\lambda_{M}, \lambda_{2}=\lambda_{H}$

The operating behavior of the IBP is described by (17)(19).

$\frac{\mathrm{d} P_{00}}{\mathrm{~d} t}=-\left(N_{\mathrm{S}} \lambda_{\mathrm{P}[00]}+N_{\mathrm{S}} \lambda_{\mathrm{F}[00]}\right) P_{00}$

\footnotetext{
${ }^{2}$ Semiconductor switches (MOSFETs, IGBTs and diodes) in all three systems are assumed to reliably fail closed circuit. This assumption serves to simplify the analysis and generally improves reliability compared to open or undefined impedance failures because current paths are not interrupted. In the IBP-BESS the failure of the one module's series and parallel MOSFET or in the CHB-BESS the failure of two MOSFETS in the same leg will result in the short-circuiting of the module. It is assumed that reliable fusing is included in the module to prevent catastrophic failure under these conditions. In a practical implementation the failure modes of these devices and the fusing action should be verified to ensure the overall system will behave as expected.
} 


$$
\begin{aligned}
& \frac{\mathrm{d} P_{i j}}{\mathrm{~d} t}=\left(N_{\mathrm{S}}-i+1-j\right) \lambda_{\mathrm{P}[i-1, j]} P_{(i-1) j} \\
& +\left(N_{\mathrm{S}}-j+1-i\right) \lambda_{\mathrm{F}[i, j-1]} P_{i(j-1)} \\
& -\left(N_{\mathrm{S}}-i-j\right)\left(\lambda_{\mathrm{P}[i j]}+\lambda_{\mathrm{F}[i j]}\right) P_{i j} \\
& \mathrm{MTTF}_{\mathrm{BP}}=\sum_{i=0}^{N_{\mathrm{S}}\left(1-r_{\mathrm{e}}\right)} \sum_{j=0}^{N_{\mathrm{S}}\left(1-r_{\mathrm{e}}\right)-i} P_{i j}^{*}(0)=\frac{1}{\lambda_{\mathrm{BP}}}
\end{aligned}
$$

Due to the increased DC link voltage of the IBP-BESS, a series connection of switches will typically be needed for each converter arm (this paper assumes a two-level MV converter as opposed to a more complex multi-level converter). The Markov state diagram for a converter arm as depicted in Fig.6 is described by (20)-(22). In this case $i$ represents the number of IGBTs that have failed. Transition from state $i$ to $(i+1)$ is described by a failure rate $\left(N_{\mathrm{SS}}-i\right) \lambda_{\mathrm{W}[i]}$.

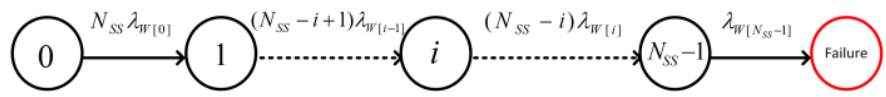

Fig. 6. Markov state transition diagram of a phase arm of the converter comprising of $N_{\text {ss }}$ IGBT switches in series.

$$
\begin{aligned}
& \frac{\mathrm{d} P_{0}}{\mathrm{~d} t}=-N_{\mathrm{SS}} \lambda_{\mathrm{W}[0]} P_{0} \\
& \frac{\mathrm{d} P_{i}}{\mathrm{~d} t}=\left(N_{\mathrm{SS}}-i+1\right) \lambda_{\mathrm{W}[i-1]} P_{i-1}-\left(N_{\mathrm{SS}}-i\right) \lambda_{\mathrm{W}[i]} P_{i} \\
& \mathrm{MTTF}_{\mathrm{arm}}=\sum_{i=0}^{N_{\mathrm{SS}}-1} P_{i}^{*}(0)=\frac{1}{\lambda_{\mathrm{arm}}}=\frac{6}{\lambda_{\mathrm{V}}}
\end{aligned}
$$

The MTTF of the IBP-BESS is then calculated using:

$$
\operatorname{MTTF}_{\mathrm{IBP}}=\frac{1}{\left(\lambda_{\mathrm{A}}+\lambda_{\mathrm{BP}}+\lambda_{\mathrm{V}}\right)}
$$

\section{Cascaded H-Bridge system reliability}

For the CHB-BESS the reliability of each phase is calculated based on (24)-(27), according to the Markov state diagram presented in Fig. 5. At state $i j, i$ denotes the number of converter modules that are not operational due to a failure in the battery module and are bypassed using the H-bridge MOSFETs and $j$ denotes the number of modules that failed due to a fault in the H-bridge and are now bypassed. The failure rates associated with a transition from $i j$ to $(i+1) j$ or $i(j+1)$ are $\left(N_{\mathrm{HB}}-i-j\right) \lambda_{\mathrm{M}[i j]}$ and $\left(N_{\mathrm{HB}}-i-j\right) 4 \lambda_{\mathrm{H}[i j]}$ respectively.

$$
\frac{\mathrm{d} P_{00}}{\mathrm{~d} t}=-N_{\mathrm{HB}}\left(\lambda_{\mathrm{M}[00]}+\lambda_{\mathrm{H}[00]}\right) P_{00}
$$

$$
\begin{aligned}
& \frac{\mathrm{d} P_{i j}}{\mathrm{~d} t} \\
& =\left(N_{\mathrm{HB}}-i+1-j\right) \lambda_{\mathrm{M}[i-1, j]} P_{(i-1), j} \\
& +\left(N_{\mathrm{HB}}-i-j+1\right) \lambda_{\mathrm{H}[i, j-1]} P_{i,(j-1)} \\
& -\left(N_{\mathrm{HB}}-i-j\right)\left(\lambda_{\mathrm{M}[i j]}+\lambda_{\mathrm{H}[i j]}\right) P_{i j} \\
& \mathrm{MTTF}_{\Theta}=\sum_{i=0}^{N_{\mathrm{HB}}\left(1-r_{\mathrm{e}}\right)} \sum_{j=0}^{N_{\mathrm{HB}}\left(1-r_{\mathrm{e}}\right)-i} P_{i j}^{*}(0) \\
& =\frac{1}{\lambda_{\Theta}}
\end{aligned}
$$

The MTTF of the three phase CHB-BESS is given by

$$
\mathrm{MTTF}_{\mathrm{CHB}}=\frac{1}{3 \lambda_{\Theta}}
$$

\section{CASE STUDY}

1MW, $1 \mathrm{MWh}$ BESSs of each of the three types are now compared using the preceding analysis at unity power factor.

\begin{tabular}{|c|c|c|c|}
\hline & PB-BESS & IBP-BESS & CHB-BESS \\
\hline $\begin{array}{c}\text { Number of } \\
\text { power blocks }\end{array}$ & 10 & 1 & 1 \\
\hline $\begin{array}{c}\text { Module } \\
\text { configuration }\end{array}$ & $5 \mathrm{~S}$ & $5 \mathrm{~S}$ & $5 \mathrm{~S}$ \\
\hline $\begin{array}{l}\text { Battery pack } \\
\text { (cells) }\end{array}$ & $\begin{array}{l}315 \mathrm{~S} 10 \mathrm{P} \\
\text { (each PB) }\end{array}$ & $\begin{array}{l}15,000 \mathrm{~S} 2 \mathrm{P} \\
\text { (in IBP) }\end{array}$ & $\begin{array}{c}10,000 \mathrm{~S} \\
\text { (per phase) }\end{array}$ \\
\hline Transformers & $\begin{array}{c}10 \\
\text { (transformer turns } \\
\text { ratio } 1: 28,99 \% \\
\text { efficiency) } \\
\end{array}$ & (none) & (none) \\
\hline $\begin{array}{c}\text { Balancing } \\
\text { circuit }\end{array}$ & $\begin{array}{c}6,300 \\
\text { MOSFETs } \\
\text { (IR } \\
\text { IRL6283MTR) } \\
6,300 \\
\text { resistors } \\
\end{array}$ & $\begin{array}{c}9,000 \\
\text { MOSFETs } \\
\text { (IR } \\
\text { IRL6283MTR) }\end{array}$ & $\begin{array}{c}24,000 \\
\text { MOSFETs } \\
\text { (IR }\end{array}$ \\
\hline Converter & $\begin{array}{c}60 \text { IGBTS } \\
\text { (6 per PB) } \\
\text { (Infineon } \\
\text { FF600R12ME4) }\end{array}$ & $\begin{array}{c}\text { 108 IGBTs } \\
\text { (18 IGBTs per } \\
\text { arm) } \\
\text { (Infineon } \\
\text { FF200R33KF2C) }\end{array}$ & IRL6283MTR) \\
\hline $\begin{array}{c}\text { Total } \\
\text { apparent } \\
\text { power of } \\
\text { switches } \\
\text { (MVA) }\end{array}$ & $\begin{array}{c}43.20 \\
\text { (converter) } \\
+25.20 \\
\text { (balancing) } \\
=68.40 \\
\end{array}$ & $\begin{array}{c}71.28 \\
\text { (converter) } \\
+36.00 \\
\text { (balancing) } \\
=107.28 \\
\end{array}$ & $\begin{array}{c}96.00 \\
\text { (all H-bridge } \\
\text { circuits) }\end{array}$ \\
\hline
\end{tabular}
The construction of each system is presented in Table I. The PB-BESS uses $5 \%$ additional cells to compensate for the loss in accessible capacity due to the lack of active balancing (31,500 15Ah lithium titanate cells compared to 30,000 for the IBP and CHB). The energy redundancy ratio is the same $\left(r_{\mathrm{e}}=0.9\right)$ for all three systems $(3,150$ redundant cells for the $\mathrm{PB}$ and 3,000 for the IBP and CHB). The modules of the PBBESS include a passive balancing circuit (shunt resistor and MOSFET switch for each module); these components are not included in the IBP and CHB-BESSs because these systems perform active balancing. Due to the higher DC link voltage of the IBP-BESS compared to the PB-BESS, each converter arm includes 18 switches in series.

\section{TABLE I}

Detailed characteristics of the three BESSs. 


\section{A. Power loss analysis}

A breakdown of system losses for the three cases is presented in Fig. 7. The PB-BESS and IBP-BESS have almost the same losses in the battery pack because similar DC currents flow in all cells. The battery losses in the CHB are increased due to the pulsed nature of the cell current (high peak-to-rms current ratio). As discussed previously, power losses due to passive balancing in the PB-BESS are not included in this analysis; in practice a small increase in average losses should be expected. Balancing losses are zero in the CHB-BESS since they are included in the power converter losses as part of normal operation. Although there is a significantly higher number of switches in the current path in the CHB-BESS, there is no centralized converter and the power electronics losses are actually reduced compared to the IBP-BESS due to the very low on-state resistance of the MOSFETs coupled with their low switching frequency. Switching losses are proportionally larger for the IBP due to the series connection of high-voltage IGBTs used to form the two-level MV converter; in practice, a multi-level converter would likely be employed which could deliver some reduction in switching loss.

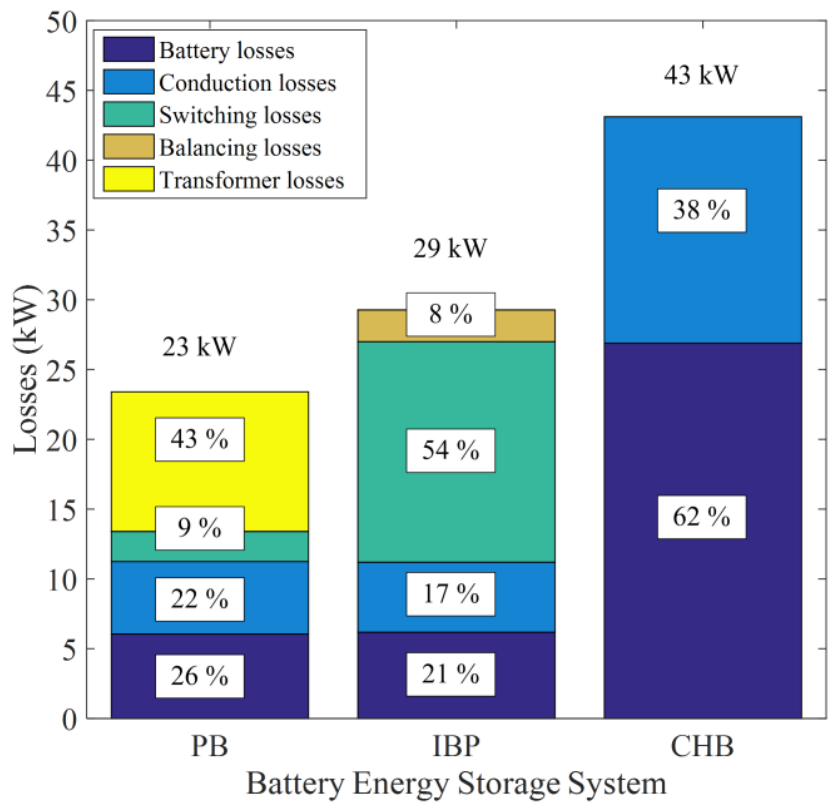

Fig. 7. Loss breakdown for the three BESS.

\section{B. Reliability analysis}

The failure rates for the different components in each system and total system MTTF are presented in Table II based on individual component models described in the Appendix.

The failure rate of the PB-BESS is highly dependent on the failure rate of the battery string because a single cell failure will result in the failure of the whole string (string failure is 20 times more likely than power converter failure).

In the IBP-BESS, due to the high battery pack voltage, each arm of the converter comprises 18 IGBTs connected in series resulting in an increased converter failure rate compared to the PB-BESS. However, the overall system MTTF of the IBP-BESS is greater than the PB-BESS due to the much higher reliability of the battery pack. The significant decrease in the failure rate of the battery pack, although the IBP-BESS includes 95 times as many cells as a single battery string in the PB-BESS (30,000 compared to 315), is due to the additional MOSFETs in the pack, which enable the IBP-BESS to isolate single module faults in the battery pack by bypassing only two parallel modules rather than a whole string of modules.

For the CHB-BESS, the failure rates for the battery pack and the converter are not calculated separately since each battery module is integrated with an H-bridge converter. This system has an increased MTTF compared to the PB-BESS due to the ability to isolate single modules in case of failure. However, its reliability is decreased compared to the IBPBESS due to the increased number of MOSFETs used (four rather than two per module).

TABLE I I

Failure rates and MTTF of the three BESSs.

\begin{tabular}{c|c|c|c}
\hline $\begin{array}{c}\text { Failure rates } \\
\text { (failures/106} \mathbf{h})\end{array}$ & PB-BESS & IBP-BESS & CHB-BESS \\
\cline { 1 - 2 } Battery & $\begin{array}{c}681 \\
\text { (string } \\
\text { of 315 cells) }\end{array}$ & $\begin{array}{c}235 \\
\text { (IBP of } \\
30,000 \text { cells) }\end{array}$ & \multirow{2}{*}{$\begin{array}{c}\text { Battery } \\
\text { integrated in } \\
\text { converter }\end{array}$} \\
Converter & $\begin{array}{c}32 \\
\text { (each PB } \\
\text { converter) }\end{array}$ & $\begin{array}{c}57 \\
\text { (single large } \\
\text { converter) }\end{array}$ & \\
\hline System & 6087 & 292 & 528 \\
\hline $\begin{array}{c}\text { MTTF } \\
\text { of the system (h) }\end{array}$ & 164 & 3,424 & 1,895 \\
\hline
\end{tabular}

\section{Notes on the cell failure model}

The Markov-Based models used in this study require the state dependent cell failure rate to be a constant function of time. In reality, due to the aging mechanisms of lithium-ion cells, the failure rate of the cell is likely to be an increasing function of time [36]. In order to explore the effect of this time dependency, the reliability study is repeated for different base cell failure rates in Fig. 8. According to Fig. 8, for a very low cell failure rate $\left(\frac{\lambda_{\mathrm{C} 0}^{\prime}}{\lambda_{\mathrm{C} 0}} \leq 10^{-3}\right.$, where $\lambda_{\mathrm{C} 0}$ is the base failure rate used in this study and $\lambda_{\mathrm{C} 0}^{\prime}$ the varying base cell failure rate) the MTTF of the PB-BESS is much improved despite the lack of controllability over series connected modules, since the failure rate is in this case dictated by the power electronics only. This failure rate represents very reliable cells, for example very high quality cells at the beginning of their life.

As the failure rate of the cells increases, corresponding to for example, cells of lower quality and/or cells that have aged, the IBP-BESS and CHB-BESS have much higher reliability than the PB. The CHB-BESS is slightly less reliable than the IBP-BESS because of the increased cell temperature (caused by increased cell losses as a result of the pulsed cell current in the CHB-BESS). The higher temperature leads to reduced cell reliability and therefore a decrease in the MTTF of the system. This effect begins to dominate when cells become significantly less reliable than the MOSFETs.

In order to further evaluate the effect of temperature on failure rate, the MTTF for each system is calculated assuming 
all components operate at ambient temperature (corresponding to, for example, very low $\mathrm{C}$ rates or highly effective cooling). As expected, reliability is improved in all cases, demonstrating that thermal management of the cells and power electronics is an important aspect of BESS design. The effect of temperature on MTTF is more obvious in the PB-BESS and IBP-BESS than for the CHB-BESS when cell failure rate is low (i.e. when MTTF of the system is mostly dependent on converter reliability) since MOSFET temperature rise in the distributed converter of the CHB-BESS is much lower than IGBT temperature rise in the centralized converter of the PB-BESS and IBP-BESS. However, when the failure rate of the cells becomes dominant, a larger increase in the MTTF of the CHBBESS becomes visible. Again, this stems from the pulsed nature of the cell current in the CHB-BESS in contrast to the DC current the cells experience in the PB-BESS and IBPBESS.

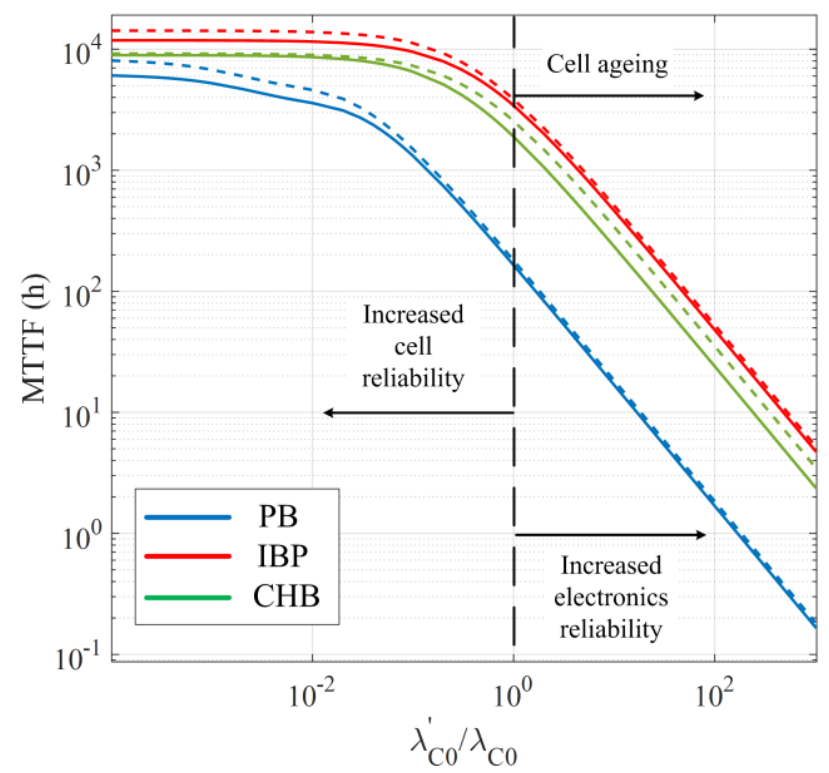

Fig. 8. MTTF for different cell failure rates $\lambda_{\text {li }}$ compared to the base failure rate $\lambda_{\text {lio }}$ used in this study. Dotted lines represent results with no temperature dependence of failure rates. Note that $\frac{\lambda_{M O S}}{\lambda_{l i 0}}=0.33$ and $\frac{\lambda_{I G B T}}{\lambda_{\text {lio }}}=0.8$, i.e. in the base case individual switches are assumed to be slightly more reliable than individual cells.

\section{Cost analysis}

The total capital cost of the three systems is presented in Table III. In order to compare reliability and capital cost a 'reliability figure of merit' (RFoM) index is used [30].

$$
\mathrm{RFoM}=\frac{\eta \mathrm{MTTF}}{\mathrm{CC}}
$$

where CC is the capital cost of each system in $\$ / \mathrm{kWh}$. The cost per unit energy is divided by the round-trip efficiency of the system $(\eta)$ in order to obtain the 'cost per useful energy' [37].

The cost of lithium ion cells is currently approximately $\$ 300 / \mathrm{kWh}$ according to [38]. The cost of the rest of the components is based on supplier data [39]. Table III shows the IBP-BESS and the CHB-BESS have very similar and much improved RFoM compared to the PB-BESS: they both offer lower capital costs but very greatly improved reliability which outweighs a slight loss in efficiency. Although the CHB-BESS utilizes three times as many individual switches when compared to the IBP, the capital cost is significantly lower due to the use of many low voltage MOSFETs with a lower costper-kVA than the few high voltage IGBTs used in the IBPBESS.

TABLE III

Cost breakdown and RFoM of the three BESSs.

\begin{tabular}{c|c|c|c}
\hline Capital Cost (\$) & PB-BESS & IBP-BESS & CHB-BESS \\
\hline Battery pack & 315,000 & 300,000 & 300,000 \\
\hline Balancing circuit & 10,761 & 7,688 & - \\
\hline Converter & 4,945 & 30,496 & 20,499 \\
\hline Transformer & 34,800 & - & - \\
\hline $\begin{array}{c}\text { Total capital cost per } \\
\text { kWh (CC) }\end{array}$ & 365,506 & 338,184 & 320,499 \\
\hline System efficiency ( $\boldsymbol{\eta})$ & 0.977 & 0.971 & 0.957 \\
\hline $\begin{array}{c}\text { Cost per unit energy } \\
\text { (\$/kWh) }\end{array}$ & 374,111 & 348,284 & 334,900 \\
\hline $\begin{array}{c}\text { MTTF of the system } \\
\text { (h) }\end{array}$ & 164 & 3,424 & 1,895 \\
\hline $\begin{array}{c}\text { RFoM (normalized to } \\
\text { the PB-BESS) }\end{array}$ & 1 & 22 & 13 \\
\hline \multicolumn{2}{|c}{}
\end{tabular}

\section{CONCLUSIONS}

This paper has presented an approach for evaluating competing BESS designs. Analytical expressions for power losses (converter losses and cell losses) were used to produce variations in component failure rates that depend on the operating state of the system. The possible operating states of each BESS were examined using a Markov-based modelling approach that incorporates information regarding system configuration in order to calculate overall system MTTF. This type of analysis is particularly relevant when considering grid scale BESSs with a large number of cells $\left(>10^{4}\right)$ where it shows that unless cell reliability is exceptionally high it is advantageous to implement a "power electronics enhanced battery pack' (such as the IBP) or a distributed converter (such as the CHB). Due to the perceived increase in the 'quantity' of power electronics, the practical feasibility of such systems may be disputed on grounds of cost and reliability. However, this study has shown that as long as the semiconductor devices used are of similar reliability to the cells, overall system reliability can be increased by over an order of magnitude, depending on the particular design decisions made. The enhanced reliability stems from the fact that the IBP-BESS and CHB-BESS systems are less vulnerable to module failure since a module can be isolated without interrupting operation (i.e. without causing many other modules to become inaccessible). In contrast, in a conventional BESS configuration, the converter acts as a single point of failure for all (or in the case of the PB-BESS, a very significant fraction) of the system. It should be noted that this study has only included the power components in the reliability model and not considered the reliability of the supporting electronics (control system, gate drives etc.) These components may have 
significant impact on overall system reliability, especially in the case of the relatively complicated IPB-BESS and CHBBESS designs which contain many more controllable power electronic components when compared to the IBP-BESS.

In all cases, the cost of the battery pack was observed to be the dominant component in the capital cost of the BESS. Systems such as the IBP-BESS and CHB-BESS are therefore also attractive because they provide in-built active balancing capability at no additional cost. This provides a valuable return on investment by increasing cell utilization, thereby reducing the number of cells required to deliver a given system energy capacity.

The results in this paper support the integration of power electronics more deeply within BESSs, either in the form of the IBP, CHB or other topologies that can provide finegrained control of small groups of cells, as this will provide significant cell management advantages and a dramatic increase in system reliability.

\section{APPENDIX}

The failure rates used in this study are based primarily on MIL-HDBK-217F [34]. However, if other component failure models are used [40], the general approach presented in this paper remains valid.

The Markov-based modelling approach requires a constant failure rate for all system components. According to [41] the base failure rate of the lithium ion cell is modelled as

$\lambda_{\mathrm{C} 0}=\frac{1}{\mathrm{MTTF}_{\mathrm{C}}}$

where $\mathrm{MTTF}_{\mathrm{C}}$ is the average life of the cell. For a typical lithium ion cell with a life equal to $10^{4}$ cycles, the base cell failure rate is $\lambda_{\mathrm{C} 0}=2$ failures $/ 10^{6}$ Hours (in the range of typical MOSFET failure rates) [42]. The effect of cell temperature on the failure rate of the cell is modelled using (42) where a temperature rise of $\Delta T$ above ambient $\left(T_{\mathrm{A}}\right)$ causes the failure rate of the cell to increase by a factor of $c_{\mathrm{T}}$ [43].

$\lambda_{\mathrm{C}}=\lambda_{\mathrm{C} 0} c_{\mathrm{T}}^{\frac{T_{\mathrm{C}}-T_{\mathrm{A}}}{\Delta T}}$

Where $T_{\mathrm{C}}=T_{\mathrm{A}}+P_{\mathrm{C}} R_{\mathrm{th}} \mathrm{C}, T_{\mathrm{A}}=25{ }^{\circ} \mathrm{C}$ is the ambient temperature, $R_{\mathrm{th}_{\mathrm{C}}}=10^{\circ} \mathrm{C} / \mathrm{W}$ is the thermal resistance of the cell, $\Delta T=10{ }^{\circ} \mathrm{C}$ and $c_{\mathrm{T}}=1.5$. The internal cell resistance $R_{\mathrm{C}}$ used in the calculation of cell power losses $\left(P_{\mathrm{C}}\right)$ is $1 \mathrm{~m} \Omega$ leading to temperature rises of up to $12{ }^{\circ} \mathrm{C}$ in this study under worst-case conditions.

The failure rates for the diodes, MOSFETs and capacitors are also derived using the MIL-HDBK-217F. A change in the steady state of the system results to a varying failure rate due to the change in the temperature and voltage stress $\pi$ factors. The thermal resistances of the MOSFET and IGBT junctionto-ambient are taken to be twice the junction-to-case resistances given in the manufactures data sheet.

Since MIL-HDBK-217F was last updated in 1991 it does not include information about the calculation of IGBT failure rates. According to [44] the failure rate for the IGBTs can be calculated using the base failure rate of MOSFETs and the $\pi$ factors of bipolar transistors.

The failure rate for a liquid filled transformer $\left(\lambda_{\mathrm{X}}\right)$ is 0.468 failures $/ 10^{6}$ hours (no temperature dependent failure rates were implemented for this component) [45].

\section{REFERENCES}

[1] T. Feehall, A. Forsyth, R. Todd, M. Foster, D. Gladwin, D. Stone, et al., "Battery energy storage systems for the electricity grid: UK research facilities," in The 8th IET International Conference on Power Electronics, Machines and Drives (PEMD) 2016, 2016.

[2] W. Huang and J. A. Abu Qahouq, "Energy sharing control scheme for state-of-charge balancing of distributed battery energy storage system," IEEE Trans. Ind. Electron., vol. 62, pp. 2764-2776, 2015.

[3] V. Fernão Pires, E. Romero-Cadaval, D. Vinnikov, I. Roasto, and J. F. Martins, "Power converter interfaces for electrochemical energy storage systems - A review," Energy Conversion and Management, vol. 86 , pp. $453-475,10 / / 2014$.

[4] B. Kenney, K. Darcovich, D. D. MacNeil, and I. J. Davidson, "Modelling the impact of variations in electrode manufacturing on lithium-ion battery modules," Journal of Power Sources, vol. 213, pp. 391-401, 2012.

[5] M. Daowd, N. Omar, P. Van Den Bossche, and J. Van Mierlo, "Passive and active battery balancing comparison based on MATLAB simulation," in Vehicle Power and Propulsion Conference (VPPC), 2011 IEEE, 2011, pp. 1-7.

[6] C.-H. Kim, M.-Y. Kim, H.-S. Park, and G.-W. Moon, "A modularized two-stage charge equalizer with cell selection switches for seriesconnected lithium-ion battery string in an HEV," IEEE Trans. Power Electron., vol. 27, pp. 3764-3774, 2012.

[7] M. T. Lawder, B. Suthar, P. W. Northrop, S. De, C. M. Hoff, O. Leitermann, et al., "Battery energy storage system (BESS) and battery management system (BMS) for grid-scale applications," Proceedings of the IEEE, vol. 102, pp. 1014-1030, 2014.

[8] J. I. Y. Ota, T. Sato, and H. Akagi, "Enhancement of Performance, Availability, and Flexibility of a Battery Energy Storage System Based on a Modular Multilevel Cascaded Converter (MMCC-SSBC)," IEEE Trans. Power Electron. , vol. 31, pp. 2791-2799, 2016.

[9] W. G. Hurley, W. H. Wolfle, and J. G. Breslin, "Optimized transformer design: inclusive of high-frequency effects," IEEE Trans. Power Electron., vol. 13, pp. 651-659, 1998.

[10] A. Manenti, A. Abba, A. Merati, S. M. Savaresi, and A. Geraci, "A new BMS architecture based on cell redundancy," IEEE Trans. Ind. Electron., vol. 58, pp. 4314-4322, 2011.

[11] F. Baronti, G. Fantechi, R. Roncella, and R. Saletti, "Design of a module switch for battery pack reconfiguration in high-power applications," in Industrial Electronics (ISIE), 2012 IEEE International Symposium on, 2012, pp. 1330-1335.

[12] M. Vasiladiotis and A. Rufer, "Analysis and control of modular multilevel converters with integrated battery energy storage," IEEE Trans. Power Electron., vol. 30, pp. 163-175, 2015.

[13] L. Maharjan, S. Inoue, H. Akagi, and J. Asakura, "State-of-charge (SOC)-balancing control of a battery energy storage system based on a cascade PWM converter," IEEE Trans. Power Electron., vol. 24, pp. 1628-1636, 2009.

[14] L. Maharjan, T. Yamagishi, and H. Akagi, "Active-power control of individual converter cells for a battery energy storage system based on a multilevel cascade PWM converter," IEEE Trans. Power Electron., vol. 27, pp. 1099-1107, 2012.

[15] C. R. Birkl, D. F. Frost, A. M. Bizeray, R. R. Richardson, and D. A. Howey, "Modular converter system for low-cost off-grid energy storage using second life li-ion batteries," in Global Humanitarian Technology Conference (GHTC), 2014 IEEE, 2014, pp. 192-199.

[16] C. Patsios, B. Wu, E. Chatzinikolaou, D. J. Rogers, N. Wade, N. P. Brandon, et al., "An integrated approach for the analysis and control of grid connected energy storage systems," Journal of Energy Storage, vol. 5, pp. 48-61, 2016.

[17] G. Kalcon, G. P. Adam, O. Anaya-Lara, G. Burt, and K. Lo, "Analytical efficiency evaluation of two and three level VSC-HVDC transmission links," International Journal of Electrical Power \& Energy Systems, vol. 44, pp. 1-6, 2013. 
[18] D. Graovac, M. Purschel, and A. Kiep, "MOSFET power losses calculation using the data-sheet parameters," Infineon application note, vol. 1,2006

[19] E. Chatzinikolaou and D. J. Rogers, "Cell SoC Balancing Using a Cascaded Full Bridge Multilevel Converter in Battery Energy Storage Systems," IEEE Trans. Ind. Electron., vol. PP, pp. 1-1, 2016.

[20] (09/09/2016). Schneider Electric. Available: http://mt.schneiderelectric.be/Main/tfo/catalogue/an_IEC.pdf

[21] L. Wu, J. Qin, M. Saeedifard, O. Wasynczuk, and K. Shenai, "Efficiency evaluation of the modular multilevel converter based on $\mathrm{Si}$ and $\mathrm{SiC}$ switching devices for medium/high-voltage applications," IEEE Trans. Electron Devices, vol. 62, pp. 286-293, 2015.

[22] G. J. Offer, V. Yufit, D. A. Howey, B. Wu, and N. P. Brandon, "Module design and fault diagnosis in electric vehicle batteries," Journal of Power Sources, vol. 206, pp. 383-392, 2012.

[23] J. Zhang, S. Ci, H. Sharif, and M. Alahmad, "Modeling discharge behavior of multicell battery," IEEE Trans. Energy Convers., vol. 25, pp. 1133-1141, 2010.

[24] T. Bruen and J. Marco, "Modelling and experimental evaluation of parallel connected lithium ion cells for an electric vehicle battery system," Journal of Power Sources, vol. 310, pp. 91-101, 2016.

[25] T. Baumhöfer, M. Brühl, S. Rothgang, and D. U. Sauer, "Production caused variation in capacity aging trend and correlation to initial cell performance," Journal of Power Sources, vol. 247, pp. 332-338, 2014.

[26] A. Ristow, M. Begović, A. Pregelj, and A. Rohatgi, "Development of a methodology for improving photovoltaic inverter reliability," IEEE Trans. Ind. Electron., vol. 55, pp. 2581-2592, 2008.

[27] S. V. Dhople, A. Davoudi, A. D. Domínguez-García, and P. L. Chapman, "A unified approach to reliability assessment of multiphase DC-DC converters in photovoltaic energy conversion systems," IEEE Trans. Power Electron., vol. 27, pp. 739-751, 2012.

[28] E. Kostandyan and K. Ma, "Reliability estimation with uncertainties consideration for high power IGBTs in 2.3 MW wind turbine converter system," Microelectronics Reliability, vol. 52, pp. 2403-2408, 2012.

[29] C. Busca, R. Teodorescu, F. Blaabjerg, S. Munk-Nielsen, L. Helle, T. Abeyasekera, et al., "An overview of the reliability prediction related aspects of high power IGBTs in wind power applications," Microelectronics Reliability, vol. 51, pp. 1903-1907, 2011.

[30] M. Boettcher, J. Reese, and F. W. Fuchs, "Reliability comparison of fault-tolerant 3L-NPC based converter topologies for application in wind turbine systems," in Industrial Electronics Society, IECON 201339th Annual Conference of the IEEE, 2013, pp. 1223-1229.

[31] C. W. Zhang, T. Zhang, N. Chen, and T. Jin, "Reliability modeling and analysis for a novel design of modular converter system of wind turbines," Reliability Engineering \& System Safety, vol. 111, pp. 86-94, 2013.

[32] B. Abdi, A. H. Ranjbar, G. B. Gharehpetian, and J. Milimonfared, "Reliability considerations for parallel performance of semiconductor switches in high-power switching power supplies," IEEE Trans. Ind. Electron. , vol. 56, pp. 2133-2139, 2009.

[33] M. Arifujjaman, "A comprehensive power loss, efficiency, reliability and cost calculation of a $1 \mathrm{MW} / 500 \mathrm{kWh}$ battery based energy storage system for frequency regulation application," Renewable Energy, vol. 74, pp. 158-169, 2015.

[34] U. S. o. A. D. o. Defense, Military Handbook: Reliability Prediction of Electronic Equipment: MIL-HDBK-217F: 2 December 1991: Department of defense, 1991.

[35] F. Richardeau and T. T. L. Pham, "Reliability calculation of multilevel converters: Theory and applications," IEEE Trans. Ind. Electron., vol. 60, pp. 4225-4233, 2013.

[36] S.-W. Eom, M.-K. Kim, I.-J. Kim, S.-I. Moon, Y.-K. Sun, and H.-S. Kim, "Life prediction and reliability assessment of lithium secondary batteries," Journal of Power Sources, vol. 174, pp. 954-958, 2007.

[37] B. Zakeri and S. Syri, "Electrical energy storage systems: A comparative life cycle cost analysis," Renewable and Sustainable Energy Reviews, vol. 42, pp. 569-596, 2015.

[38] R. E. Ciez and J. Whitacre, "The cost of lithium is unlikely to upend the price of Li-ion storage systems," Journal of Power Sources, vol. 320, pp. 310-313, 2016.

[39] (10/05/2016). Mouser Electronics, Inc. Available: http://www.mouser.co.uk/

[40] M. Held and K. Fritz, "Comparison and evaluation of newest failure rate prediction models: FIDES and RIAC 217Plus," Microelectronics Reliability, vol. 49, pp. 967-971, 2009.
[41] X. Liu, J. Zou, and X. Zhang, "Investigations on the reliability of storage battery array with high capability," in Condition Monitoring and Diagnosis, 2008. CMD 2008. International Conference on, 2008, pp. 735-737.

[42] N. Mukherjee and D. Strickland, "Second life battery energy storage systems: Converter topology and redundancy selection," in Power Electronics, Machines and Drives (PEMD 2014), 7th IET International Conference on, 2014, pp. 1-6.

[43] M. Ecker, J. B. Gerschler, J. Vogel, S. Käbitz, F. Hust, P. Dechent, et $a l$., "Development of a lifetime prediction model for lithium-ion batteries based on extended accelerated aging test data," Journal of Power Sources, vol. 215, pp. 248-257, 2012.

[44] A. Stupar, D. Bortis, U. Drofenik, and J. Kolar, "Advanced setup for thermal cycling of power modules following definable junction temperature profiles," in Power Electronics Conference (IPEC), 2010 International, 2010, pp. 962-969.

[45] J. W. Aquilino, "Report of transformer reliability survey-industrial plants and commercial buildings," IEEE Trans. Ind. Appl., pp. 858-866, 1983.

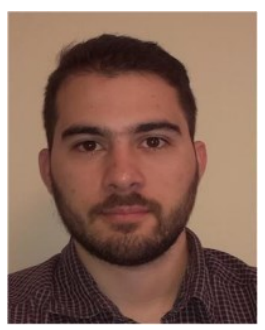

Efstratios Chatzinikolaou (S'16) received the Diploma degree in electrical and computer engineering from National Technical University of Athens, Athens, Greece, in 2013. He is currently working toward the DPhil in Engineering Science at the University of Oxford, U.K. His research interests include modular multilevel converter topologies and power electronic interfaces for battery energy storage systems.

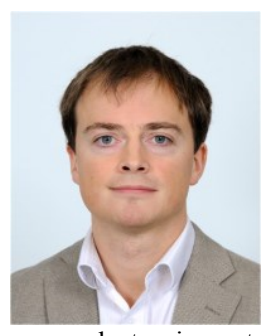

Daniel J. Rogers (M'09) received the M.Eng. and $\mathrm{Ph} . \mathrm{D}$. degrees in electrical and electronic engineering from Imperial College London, London, U.K., in 2007 and 2011 respectively. Currently, he is a Senior Research Fellow at the University of Oxford, U.K. $\mathrm{He}$ conducts research in collaboration with industry and is an investigator on EPSRC and EU research projects in the areas of power electronics, HVDC and grid-scale energy storage. His research interests include the use of medium- and large-scale power electronic systems to create flexible electrical networks capable of taking advantage of a diverse range of generation technologies. 